\title{
Assessment of Quality of Life of Hepatitis C Patients Treated By Sovaldi Drug in Viral Hepatitis Treatment Center in Ismailia Fever Hospital, Egypt
}

Ezzat El Niwehy ${ }^{1}$, Alaa Hany ${ }^{1}$, Ahmed Mohamed ${ }^{1}$, Eman Moubarak ${ }^{1}$, Esraa Ayed ${ }^{1}$, Mohamed Mousa ${ }^{1}$, Merna Abd Elatif ${ }^{1}$, Omar Mohamed $^{1}$, Reham Mohamed ${ }^{1}$, Reham Farid ${ }^{1}$, Sohila Soliman ${ }^{1}$ and Hussien Amer ${ }^{1,2}$

${ }^{1}$ Suez Canal University, Egypt

${ }^{2}$ Department of Community Medicine, Suez Canal University, Egypt

*Corresponding author: Ezzat Mahmoud EL Niwehy, Faculty of Medicine, Suez Canal University, Egypt, Tel: +201146108810; E-mail: ezzat.medo33@gmail.com Received date: February 22, 2018; Accepted date: November 21, 2018; Published date: November 27, 2018

Copyright: @ 2018 El Niwehy E, et al. This is an open-access article distributed under the terms of the Creative Commons Attribution License, which permits unrestricted use, distribution, and reproduction in any medium, provided the original author and source are credited.

\begin{abstract}
Introduction: patients with chronic liver disease are suffering from fatigue, loss of self-esteem, inability to function at work, anxiety, depression, and other emotional problems that profoundly decrease their quality of life and well-being.

Objectives: To assess the quality of life of hepatitis $\mathrm{C}$ patients receiving Sovaldi drug. To determine most common short-term side effects of Sovaldi containing regimen medication.

Methods: A descriptive cross sectional study was carried out in Viral Hepatitis Treatment Center Ismailia fever Hospital. Study population was Hepatitis c virus patients treated with regimen containing sovaldi (sovaldi+ribavirin for 12 weeks). Simple random sampling was used to select the subjects included in the study Using sample size ready-made tables, 74 patients were selected to participate in this study where an interviewing questionnaire used to collect the data by 36 RAND questionnaire.
\end{abstract}

Results: About $49 \%$ of the patients noticed change in their mode to the worst, and $5 \%$ felt depressed to the extent of suicide and about $61 \%$ of the patients were having difficulty with sleeping and concentrating. About half of the patients $(50 \%)$ were having poor role-emotional. the most common short-term side effect were Headache which was the highest (53\%) while others as(joint pain-decreasing sexual function-decreasing appetite) followed it. $35.2 \%$ were having excellent social functioning during the period of treatment of sovaldi, whereas (about $56.8 \%$ ) ranging from poor to fair social functioning.

Conclusion: the study was carried on 74 patients and the results were controversial as regarding their lifestyle affection, some people got better and others got worse especially those experienced recurrence of the disease. We recommend larger studies with large sample size to detect effectively the life style changes with medication.

Keywords Hepatitis; Sovaldi; Quality of life; Ismailia fever hospital

\section{Introduction}

Hepatitis $C$ is a liver disease caused by the hepatitis $C$ virus: the virus can cause both acute and chronic hepatitis infection, ranging in severity from a mild illness lasting a few weeks to a serious, life long illness. The hepatitis $\mathrm{C}$ virus is a blood borne virus and the most common modes of infection are through unsafe injection practices, inadequate sterilization of medical equipment, and the transfusion of unscreened blood and blood products. Hepatitis $\mathrm{C}$ virus (HCV) causes both acute and chronic infection. Acute HCV infection is usually asymptomatic, and is only very rarely associated with life-threatening disease. About $15-45 \%$ of infected persons spontaneously clear the virus within 6 months of infection without any treatment. The remaining 55-85\% of persons will develop chronic HCV infection [1].

Chronic hepatitis $\mathrm{C}$ virus (HCV) infection remains one of the most important clinical and public health problems facing modern medicine. In 2015, the Centre for Disease Control (CDC) estimates that 170 million people worldwide are living with chronic HCV infection and almost 20,000 died from HCV-related liver.
The HCV epidemic in Egypt is of a socioeconomic nature. It is mostly prevalent among lower social and economic segments of the population. Historically, it started by the parenteral anti-schistosomal (bilharzia) treatment campaigns undertaken in the 1960s and 1970s in rural areas using improperly sterilized glass syringes (tartar emetic injections(. This is behind the high HCV prevalence rate in rural compared to urban areas; $12 \%$ and $7 \%$ respectively $[2,3]$. The World Health Organization (WHO) has found that Egypt has the highest prevalence of the Hepatitis $\mathrm{C}$ virus (HCV) in the world, with approximately 22 percent of Egyptian blood donors testing positive for the deadly disease. According to HCV Advocate, the main cause of exposure in Egypt appears to be due to inadequate infection control practices and injection therapy such as blood transfusions. The highest prevalence rates of hepatitis $\mathrm{C}$ virus infection in the world have been recently reported among Egyptian blood donors and frequent recipients of transfusions and other blood products. This is the first report, however, demonstrating hepatitis $\mathrm{C}$ as the most frequent association with chronic liver disease in Egypt (World Health Organization, 1997). 
Citation: El Niwehy E, Hany A, Mohamed A, Moubarak E, Ayed E, et al. (2018) Assessment of Quality of Life of Hepatitis C Patients Treated By Sovaldi Drug in Viral Hepatitis Treatment Center in Ismailia Fever Hospital, Egypt . J Liver 7: 233. doi:10.4172/2167-0889.1000233

Page 2 of 5

Sofosbuvir (sovaldi) is a direct-acting nucleotide polymerase inhibitor that is being developed as an oral drug for the treatment of chronic HCV infection.6 Nucleotide analogues are phosphorylated within the host hepatocyte to the active nucleoside triphosphate, which competes with the natural nucleotides, thereby causing termination of RNA replication in the nascent viral genome Health-related quality of life provides an important outcome from a patient's perspective [4].

In this study we want to detect health related quality of life in hepatitis $\mathrm{c}$ patients receiving sovaldi containing regimens and the most term side effects of treatment.

\section{Aim of the Study}

We aimed at assessing the quality of life of hepatitis $c$ patients receiving regimens containing sovaldi drug and to detect the shortest side effects of treatment.

\section{Patients and methods}

Study design: A descriptive cross sectional study was carried out.

Study setting: The study was carried out in Viral Hepatitis treatment Center Ismailia fever Hospital, Egypt.

Study population: Hepatitis c virus patients treated with regimen containing sovaldi.

Inclusion criteria: All hepatitis $C$ virus patients above 18 years old of both sex taking Sovaldi containing regimenas treatment (all patients took the regimen: sovaldi+ribavirin for 12 weeks).

Exlusion criteria: We exclude patients with adjuvant hepatitis B virus and patients with hepatocellular carcinoma or other body tumors.

Sample size: Using sample size ready-made tables, 74 patients was selected to participate in this study.

$$
n=\left[\frac{z_{\alpha / 2} \mathrm{X} \sigma}{\mathrm{E}}\right]^{2}
$$

Where, $n=$ sample; size $=74$ cases; $Z$ a/2=1.96 (The critical value that divides the central $95 \%$ of the $\mathrm{Z}$ distribution from the $5 \%$ in the tail); $\sigma=$ the estimate of the standard deviation $= \pm 21.9[5,6]$.

$\mathrm{E}=$ the margin of error (=width of confidence interval).

\section{Methodology}

Approval was obtained from the research ethical committee, faculty of medicine, Suez Canal University. Details of work and aim of the research were explained to all of the participants with obtaining written and verbal consent from all of them. Data was collected by simple random sample. An interview questionnaire was followed for data collection, and we use RAND 36-item health Survey (Research and Development) in the study that was designated based on previous studies and experts' opinions. SF 36 scales are vitality, social functioning, and bodily pain, general health physical role functioning, emotional role functioning, social role functioning and mental health. Data after that were analysed by SPSS program and results were obtained on tables and figures.

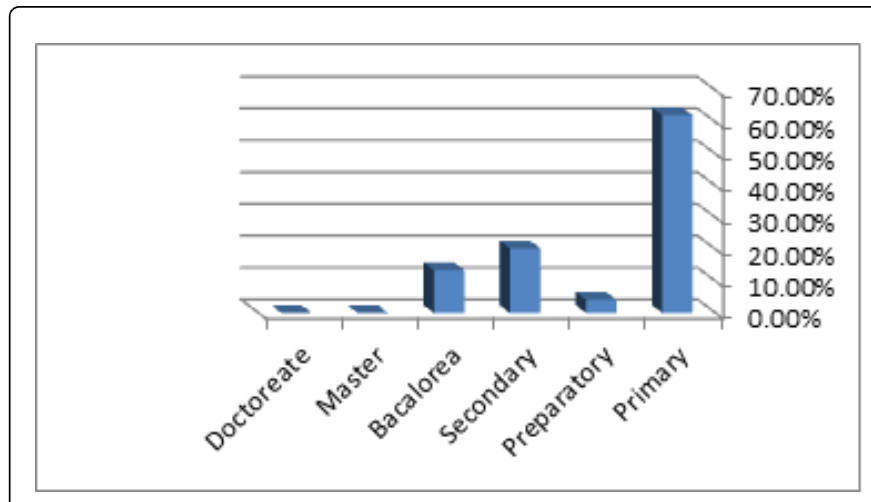

Figure 1: Distribution of patients attending Viral Hepatitis treatment Centre Ismailia fever Hospital according to their level of education ( $\mathrm{N}=74)$. Most of the patients (about $63 \%$ ) were primarily educated.

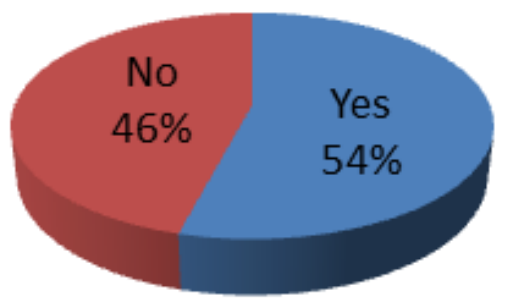

Figure 2: Distribution of patients consulted the doctor about annoying side effects $(\mathrm{N}=74) .54 \%$ of patients consulted the doctor about annoying side effects.

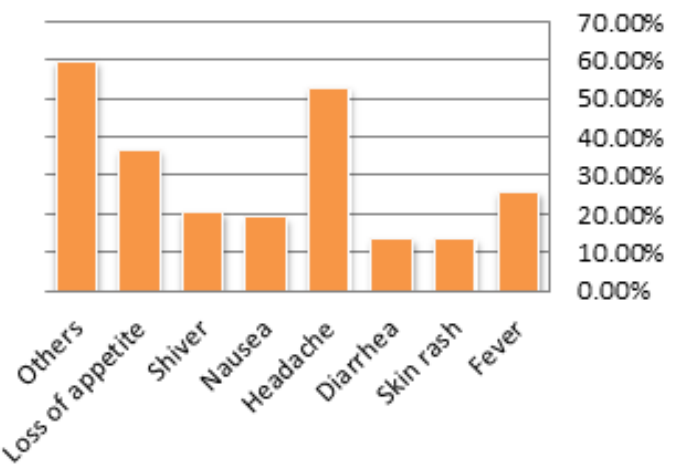

Figure 3: Distribution of common short-term side effects among patients attending Viral Hepatitis treatment Centre Ismailia fever Hospital $(\mathrm{N}=74)$. Headache was the most common short-term side effect (53\%) followed by others as (joint pain-decreasing sexual function-decreasing appetite). 
Citation: El Niwehy E, Hany A, Mohamed A, Moubarak E, Ayed E, et al. (2018) Assessment of Quality of Life of Hepatitis C Patients Treated By Sovaldi Drug in Viral Hepatitis Treatment Center in Ismailia Fever Hospital, Egypt . J Liver 7: 233. doi:10.4172/2167-0889.1000233

Page 3 of 5

\section{Results}

The current study indicating that about $35.2 \%$ of the patients were having poor physical function during the period of treatment of sovaldi (Tables 1 and 2). About half of the patients were having poor role-emotional during the period of treatment of sovaldi, on the other hand $(45.7 \%)$ were having excellent role-emotional, about $49 \%$ noticed change in their mode, and about $5 \%$ felt depressed to the extent of suicide (Tables 3 and 4 ).

\begin{tabular}{|c|c|c|}
\hline Age & No. & $\%$ \\
\hline $15-34$ & 11 & 14.9 \\
\hline $35-54$ & 37 & 50 \\
\hline $55-74$ & 26 & 35.1 \\
\hline Total & 74 & 100 \\
\hline
\end{tabular}

$50 \%$ of the patients were between $35-54$ years old

Table 1: Distribution of patients attending Viral Hepatitis treatment Centre Ismailia fever Hospital according to their age by years $(\mathrm{N}=74)$.

\begin{tabular}{|c|c|c|}
\hline Physical Functioning & No. & $\%$ \\
\hline$(100 \%-85 \%)$ & 18 & 24.3 \\
\hline$(<85 \%-75 \%)$ & 10 & 13.5 \\
\hline$(<75 \%-65 \%)$ & 8 & 10.8 \\
\hline$(<65 \%-50 \%)$ & 12 & 16.2 \\
\hline$(<50 \%)$ & 26 & 35.2 \\
\hline Total & 74 & 100 \\
\hline About $(35.2 \%)$ were having poor physical function during the period of treatment of sovaldi.
\end{tabular}

Table 2: Distribution of patients attending Viral Hepatitis treatment Centre Ismailia fever Hospital according to physical functioning $(\mathrm{N}=74)$.

About $35.2 \%$ of the patients were having excellent social functioning during the period of treatment of sovaldi, whereas about $56.8 \%$ ranging from poor to fair social function. (32.4\%) were having fair general health and (27\%) having poor general health during the period of treatment of sovaldi (Tables 5 and 6).

\begin{tabular}{|c|c|c|}
\hline Role-Physical & No & $\%$ \\
\hline$(100 \%-85 \%)$ & 24 & 32.4 \\
\hline$(<85 \%-75 \%)$ & 3 & 4 \\
\hline$(<75 \%-65 \%)$ & 0 & 0 \\
\hline$(<65 \%-50 \%)$ & 8 & 10.8 \\
\hline$(<50 \%)$ & 39 & 52.8 \\
\hline Total & 74 & 100 \\
\hline
\end{tabular}

Most of the patients (52.8\%) were having poor physical function during the period of treatment of sovaldi.

Table 3: Distribution of patients attending Viral Hepatitis treatment Centre Ismailia fever Hospital according to role-physical $(\mathrm{N}=74)$.

\begin{tabular}{|c|c|c|}
\hline Role-Emotional & No. & $\%$ \\
\hline$(100 \%-85 \%)$ & 34 & 45.7 \\
\hline$(<85 \%-75 \%)$ & 0 & 0 \\
\hline$(<75 \%-65 \%)$ & 3 & 4.3 \\
\hline$(<65 \%-50 \%)$ & 0 & 0 \\
\hline$(<50 \%)$ & 37 & 100 \\
\hline Total & 74 & 50 \\
\hline $\begin{array}{l}\text { About (50\%) were having poor role-emotional during the period of treatment of sovaldi, on the other hand } \\
(45.7 \%) \text { were having excellent role-emotional. }\end{array}$
\end{tabular}

Table 4: Distribution of patients attending Viral Hepatitis treatment Centre Ismailia fever Hospital according to role-emotional $(\mathrm{N}=74)$.

\begin{tabular}{|c|c|c|}
\hline Bodily-Pain & No. & $\%$ \\
\hline$(100 \%-85 \%)$ & 18 & 24.3 \\
\hline$(<85 \%-75 \%)$ & 4 & 5.4 \\
\hline$(<75 \%-65 \%)$ & 13 & 17.6 \\
\hline$(<65 \%-50 \%)$ & 20 & 27 \\
\hline$(<50 \%)$ & 19 & 25.7 \\
\hline Total & 74 & 100 \\
\hline About $(27 \%)$ were having fair bodily-pain during the period of treatment of sovaldi. \\
\hline
\end{tabular}

Table 5: Distribution of patients attending Viral Hepatitis treatment Center Ismailia fever Hospital according to bodily-pain $(\mathrm{N}=74)$.

$35.2 \%$ of patients were having excellent social functioning during the period of treatment of sovaldi, whereas (about 56.8\%) ranging from poor to fair social (Tables 7-9).

\begin{tabular}{|c|c|c|}
\hline General Health & No. & $\%$ \\
\hline$(100 \%-85 \%)$ & 0 & 0 \\
\hline$(<85 \%-75 \%)$ & 11 & 25.7 \\
\hline$(<75 \%-65 \%)$ & 19 & 32.4 \\
\hline$(<65 \%-50 \%) \mathrm{s}$ & 24 & 27 \\
\hline$(<50 \%)$ & 74 & 100 \\
\hline Total & 20 & \\
\hline \multicolumn{2}{|c|}{ About (32.4\%)were having fair genaral health and $(27 \%)$ having poor general health during the period of } \\
\end{tabular}

Table 6: Distribution of patients attending Viral Hepatitis treatment Center Ismailia fever Hospital according to general health $(\mathrm{N}=74)$. 


\begin{tabular}{|c|c|c|}
\hline Vitality & No. & $\%$ \\
\hline$(100 \%-85 \%)$ & 9 & 12.1 \\
\hline$(<85 \%-75 \%)$ & 7 & 9.5 \\
\hline$(<75 \%-65 \%)$ & 7 & 9.5 \\
\hline$(<65 \%-50 \%)$ & 16 & 21.6 \\
\hline$(<50 \%)$ & 35 & 47.3 \\
\hline Total & 74 & 100 \\
\hline \multicolumn{3}{|c|}{ Most of the patients $(47.3 \%)$ were having poor vitality during the period of treatment of sovalc } \\
\hline
\end{tabular}

Table 7: Distribution of patients attending Viral Hepatitis treatment Center Ismailia fever Hospital according to vitality $(\mathrm{N}=74)$.

\begin{tabular}{|c|c|c|}
\hline Social Functioning & No. & $\%$ \\
\hline$(100 \%-85 \%)$ & 26 & 35.2 \\
\hline$(<85 \%-75 \%)$ & 6 & 8 \\
\hline$(<75 \%-65 \%)$ & 0 & 0 \\
\hline$(<65 \%-50 \%)$ & 21 & 28.4 \\
\hline$(<50 \%)$ & 21 & 28.4 \\
\hline Total & 74 & 100 \\
\hline $35.2 \%$ of patients were having excellent social functioning during the period of treatment of sovaldi, \\
whereas (about 56.8\%) ranging from poor to fair social.
\end{tabular}

Table 8: Distribution of patients attending Viral Hepatitis treatment Center Ismailia fever Hospital according to social functioning $(\mathrm{N}=74)$.

\begin{tabular}{|c|c|c|}
\hline Mental Health & No. & $\%$ \\
\hline$(100 \%-85 \%)$ & 11 & 14.9 \\
\hline$(<85 \%-75 \%)$ & 9 & 12.2 \\
\hline$(<75 \%-65 \%)$ & 11 & 14.9 \\
\hline$(<65 \%-50 \%)$ & 16 & 21.5 \\
\hline$(<50 \%)$ & 27 & 36.5 \\
\hline Total & 74 & 100 \\
\hline \multicolumn{2}{|c|}{ About (36.5\%) were having poor mental health during the period of treatment of sovaldi. } \\
\hline
\end{tabular}

Table 9: Distribution of patients attending Viral Hepatitis treatment Center Ismailia fever Hospital according to mental health $(\mathrm{N}=74)$.

About $54 \%$ of patients consulted the doctor about annoying side effects that were as follow, headache was the most common short-term side effect (about 53\%) followed by others as (joint pain-increasing, sexual function-increasing appetite), about $67 \%$ were complaining of back and flank pain (Figures 1-3).

\section{Discussion}

In this study About $54 \%$ of patients consulted the doctor about annoying side effects that were as follow, headache was the most common short-term side effect (about 53\%) followed by others as (joint pain, increasing sexual function, increasing appetite), a bout $67 \%$ were complaining of back and flank pain. In another study indicating the most common side effects noted in Phase III trials of SOF and RBV only were fatigue, headache and nausea. Anemia was more common in the cohorts treated with RBV and SOF than those who received placebo [7].

\section{Regarding physical effects}

The current study indicating that about $35.2 \%$ of the patients were having poor physical function during the period of treatment of sovaldi. A study conducted by Barkhuizen et al. on 239 patients found that musculoskeletal pain was present in $70 \%$. Backache was the most common complaint (54\%), followed by morning stiffness (45\%), arthralgia (42\%), myalgia (38\%), and neck pain (33\%), pain "all over" $21 \%$. There was a significant association between hepatitis C positivity and the presence of musculoskeletal pain $(81 \%$ of $\mathrm{HCV}$-positive compared with $56 \%$ of HCV-negative patients, respectively; $\mathrm{p}=0.0001$ ). There was no relationship between musculoskeletal complaints and interferon treatment [8].

\section{Regarding psychiatric effects}

About half of the patients were having poor role-emotional during the period of treatment of sovaldi, on the other hand $(45.7 \%)$ were having excellent Role-Emotional, about $49 \%$ noticed change in their mode, and about $5 \%$ felt depressed to the extent of suicide. In another study done to assess Depression and anxiety in patients with hepatitis C: prevalence, detection rates and risk factors showing that about $24 \%$ prevalence of anxiety disorders [9].

\section{Regarding social effects}

About $35.2 \%$ of the patients were having excellent social functioning during the period of treatment of sovaldi, whereas about $56.8 \%$ ranging from poor to fair social function. In another study held in Australia aiming to examine the effect of diagnosing patients with Hepatitis C in quality of life showed that patients who are aware of their diagnosis had subjective perception of poor social functioning [10]. In another study done in London in St Mary's Hospital assessing the effect of chronic hepatitis $c$ on patient's quality of life using short form 36 symptomatology questionnaire showed that the SF36 scores that assess an individual's capacity for physical activity showed significant reductions [11]. The difference in the result could be attributed to the fact that Egypt has the highest prevalence of the Hepatitis $\mathrm{C}$ virus (HCV) in the world so the patients are more familiar to the disease than Australian patients, or the effect of the treatment on increasing their social quality of life.

\section{Regarding general health}

About (32.4\%) were having fair general health and (27\%) having poor general health during the period of treatment of sovaldi, in another study done in united states in clevand clinic foundation assess health related quality of life of chronic liver disease patients showed that about $35 \%$ of patients have no change in their global ratings of change scores and were considered stable [5]. 
Citation: El Niwehy E, Hany A, Mohamed A, Moubarak E, Ayed E, et al. (2018) Assessment of Quality of Life of Hepatitis C Patients Treated By Sovaldi Drug in Viral Hepatitis Treatment Center in Ismailia Fever Hospital, Egypt . J Liver 7: 233. doi:10.4172/2167-0889.1000233

Page 5 of 5

\section{Regarding role-emotional scale}

About (50\%) were having poor role-emotional during the period of treatment of sovaldi, on the other hand (45.7\%) were having excellent Role-Emotional. The question assessing to what extent feeling worry affect hepatitis $\mathrm{C}$ patients life, showing that about $31 \%$ have no effect, $17 \%$ have mild effect, $18 \%$ have moderate effect, $24 \%$ have severe effect and $10 \%$ have drastic effect. In another study done to assess Depression and anxiety in patients with hepatitis C: prevalence, detection rates and risk factors showing that about $24 \%$ prevalence of anxiety disorders [12].

\section{Conclusion}

We reached that half of the patients $(50 \%)$ were having poor roleemotional during the period of treatment of sovaldi, on the other hand (45.7\%) were having excellent Role-Emotional, about (47.3\%) were having poor Vitality during the period of treatment of sovaldi, $50 \%$ of the patients were between 35-54 years old and most of them (35.2\%) were having poor physical function during the period of treatment. The most common short-term side effect were: Headache which was the highest (53\%) and others as (joint pain-increasing sexual functionincreasing appetite) followed it, most of patients about (61\%) were having difficulty with sleeping and concentrating, and (about 49\%) noticed change in their mode, and about (5\%) felt depressed to the extent of suicide.

\section{References}

1. Poynard T, Bedossa P, Opolon P (1997) Natural history of liver fibrosis progression in patients with chronic hepatitis C. The Obsvirc, Metavir, Clinivir, and Dosvirc groups. Lancet 349: 825-832.
2. El-Zanaty F, Way A (2009) Egypt Demographic and Health Survey 2008.

3. Yock Young D, Yeoh GC (2008) Liver stem cells: A scientific and clinical perspective. J Gastroenterol Hepatol 23: 687-698.

4. Testa MA, Simonson DC (1996) Assessment of quality-of-life outcomes. N Engl J Med 334: 835-840.

5. Younossi ZM, Guyatt G, Kiwi M, Boparai N, King D (1999) Development of a disease specific questionnaire to measure health related quality of life in patients with chronic liver disease. Gut 45: 295-300.

6. Kamel MA, Ebeid SM, Elakkad RM, Shafeek NE (2015) Prevalence of Anemia among community dwelling elderly in Dakahlia as a representative of rural areas in Egypt and its impact on their functional status. Adv Aging Res 04: 168-176.

7. Lam B, Henry L, Younossi Z (2014) Sofosbuvir (Sovaldi) for the treatment of hepatitis C. Expert Rev Clin Pharmacol 7: 555-566.

8. Barkhuizen A, Rosen HR, Wolf S, Flora K, Benner K et al. (1999) Musculoskeletal pain and fatigue are associated with chronic hepatitis C: a report of 239 hepatology clinic patients. Am J Gastroenterol 94: 1355-1360.

9. Golden J, O'Dwyer AM, Conroy RM (2005) Depression and anxiety in patients with hepatitis C: prevalence, detection rates and risk factors. Gen Hosp Psychiatry 27: 431-438.

10. Rodger AJ, Damien J, Thompson SC, Lanigan A, Crofts N (2003) The impact of diagnosis of hepatitis $\mathrm{C}$ virus on quality of life. Hepatol 30: 1299-1301.

11. Foster GR, Goldin RD, Thomas HC (1998) Chronic hepatitis C virus infection causes a significant reduction in quality of life in the absence of cirrhosis. Hepatol 27: 209-212.

12. Golden J, O'Dwyer AM, Conroy RM (2005) Depression and anxiety in patients with hepatitis C: prevalence, detection rates and risk factors. Gen Hosp Psychiatry 27: 431-438. 